\title{
Functional significance of CD57 expression on human NK cells and relevance to disease
}

\section{Carolyn M. Nielsen, Matthew J. White, Martin R. Goodier and Eleanor M. Riley*}

Department of Immunology and Infection, London School of Hygiene and Tropical Medicine, London, UK

\section{Edited by:}

Yenan Bryceson, Karolinska Institutet, Sweden

\section{Reviewed by:}

William Garrow Kerr, SUNY Upstate Medical University, USA

Björn Önfelt, Karolinska Institutet, Sweden

\section{*Correspondence:}

Eleanor M. Riley, Department of Immunology and Infection, London School of Hygiene and Tropical

Medicine, Room 236, Keppel Street, London WC1E 7HT, UK

e-mail: eleanor.riley@Ishtm.ac.uk
Historically, human NK cells have been identified as $\mathrm{CD}^{-} \mathrm{CD}^{-} 6^{+} \mathrm{CD} 16^{ \pm}$lymphocytes. More recently it has been established that CD57 expression defines functionally discrete sub-populations of NK cells. On T cells, CD57 expression has been regarded as a marker of terminal differentiation and (perhaps wrongly) of anergy and senescence. Similarly, CD57 expression seems to identify the final stages of peripheral NK cell maturation; its expression increases with age and is associated with chronic infections, particularly human cytomegalovirus infection. However, $\mathrm{CD} 57^{+} \mathrm{NK}$ cells are highly cytotoxic and their presence seems to be beneficial in a number of non-communicable diseases. The purpose of this article is to review our current understanding of CD57 expression as a marker of NK cell function and disease prognosis, as well as to outline areas for further research.

Keywords: CD57, NK cells, HCMV infection, ageing, chronic infection, cancer, autoimmune diseases, T cells

\section{CD57 IS A MARKER OF NK CELL DIFFERENTIATION}

CD57 was first identified on cells with natural killer activity using the mouse monoclonal antibodies Human Natural Killer-1 (HNK1) (1) and Leu-7 (2) and was subsequently assigned the cluster of differentiation (CD) designation, CD57, at the fourth International Workshop of Human Leukocyte Antigens in 1989. HNK$1 /$ Leu-7/CD57 was initially believed to be uniquely expressed on NK cells - and was used to define this population $(1,3)$ - although it was soon apparent that CD57 was expressed only on a subset of functionally distinct NK cells (4). CD57 was subsequently identified on $\mathrm{CD} 8^{+} \mathrm{T}$ cells $(5-7)$ as well as cells of neural crest origin (1, $8-13)$. Indeed, it was the neuroscience community that ultimately defined CD57 as a terminally sulfated carbohydrate epitope (glucuronic acid 3-sulfate) (14-16). In neural cells, the CD57 epitope is predominantly restricted to adhesion molecules (17) but little attention has been paid to the precise identity of the molecules expressing the CD57 epitope on NK cells and T cells, precluding a full understanding of the relationship between CD57 expression and lymphocyte function. Although one study identified the CD57 epitope on the IL- 6 receptor gp130 of resting lymphocytes (18), the cells expressing CD57/gp130 were not identified and no comprehensive analysis of CD57-expressing molecules on $\mathrm{T}$ cells or NK cells has been reported.

While first characterized as an NK cell marker, CD57 has been most widely explored as a marker of replicative senescence on $\mathrm{T}$ cells (19). Under conditions of persistent immune stimulation, memory $\mathrm{T}$ cells convert from $\mathrm{CD} 28^{+} \mathrm{CD} 57^{-}$to $\mathrm{CD} 28^{-} \mathrm{CD} 57^{+}$ (20); $\mathrm{CD} 57^{+}$cells have short telomeres, low telomerase activity, low expression of cell-cycle associated genes and limited proliferative capacity $(20,21)$. However, $\mathrm{CD} 57^{+} \mathrm{CD} 28^{-} \mathrm{CD} 8^{+} \mathrm{T}$ cells can proliferate given an appropriate cytokine milieu (22), their sensitivity to apoptosis is disputed $(23,24)$, they are highly cytotoxic $(25$, 26) and express natural killer receptors (27). $\mathrm{CD} 57^{+} \mathrm{CD} 8^{+} \mathrm{T}$ cells should thus be regarded as terminally differentiated, oligoclonal populations of cytotoxic cells generated in response to chronic antigen stimulation.

In light of the $\mathrm{T}$ cell data it was suggested that CD57 may also be a marker of NK cells with poor proliferative capacity and, perhaps, a degree of immunosenescence $(21,23,28)$. Indeed, acquisition of CD57 on NK cells - following stimulation with IL-2 or coculture with target cells - correlates with maturation of the CD56 ${ }^{\mathrm{dim}} \mathrm{NK}$ cell subset, with lower expression of NKp46, NKp30, NKG2D, and NKG2A, and higher expression of CD16, LIR-1, and killer cell immunoglobulin-like receptors (KIRs) (29). Similarly, in hematopoietic stem cell transplant recipients exposed to human cytomegalovirus (HCMV) infection, differentiation of CD56 dim NK cells involves acquisition of CD57, loss of NKG2A, gain of KIRs, and changing expression of homing molecules (30). These studies, together with experiments in $\mathrm{Rag} 2^{-1-} \gamma \mathrm{cR}^{-1-}$ mice reconstituted with human hematopoietic stem cells and treated with IL-15 (30), and the observation that fetal and newborn NK cells lack CD57 (31), indicate that $\mathrm{CD} 57^{+} \mathrm{NK}$ cells differentiate from CD56 ${ }^{\mathrm{dim}} \mathrm{CD} 57^{-}$NK cells in an irreversible process with highly stable expression of CD57 likely being the final step in maturation $(30,32)$. This differentiation is accompanied by functional changes $(29,30)$ : compared with $\mathrm{CD} 57^{-}$cells, $\mathrm{CD} 57^{+} \mathrm{NK}$ cells proliferate less well in response to IL- 2 and IL-15 and produce less IFN- $\gamma$ in response to IL-12 and IL-18, consistent with their lower levels of IL-12R $\beta$ mRNA (29) and reduced surface expression of IL-2R $\beta$ and IL-18R $\alpha$ (30). On the other hand, $\mathrm{CD} 57^{+} \mathrm{NK}$ cells retain their cytolytic potential (30) and a proportion of $\mathrm{CD} 57^{+} \mathrm{NK}$ cells are able to produce IFN- $\gamma$ after crosslinking of CD16 [Ref. (29); White et al. submitted] indicating that $\mathrm{CD} 57^{+} \mathrm{NK}$ cells are intrinsically able to produce IFN- $\gamma$ but that they may have different activation requirements.

In summary, therefore, progression from $\mathrm{CD} 56^{\text {bright }}$ to $\mathrm{CD} 56^{\mathrm{dim}} \mathrm{CD} 57^{-}$to $\mathrm{CD} 56^{\mathrm{dim}} \mathrm{CD} 57^{+}$reflects a maturation pathway for NK cells $(33,34)$ and rather than being a marker of anergy or 
immunosenescence, acquisition of CD57 represents a shift toward a higher cytotoxic capacity, greater responsiveness to signaling via CD16 and natural cytotoxicity receptors (NCRs) and decreased responsiveness to cytokines $(29,35)$. The extent to which CD57 expression per se drives these changes in function, as opposed to being a marker for cells with altered expression of other attributes of a mature NK cell, is not entirely clear and may represent a fertile area for further research. In addition, a much better characterization is required of the cell surface molecules that express the CD57 epitope, the mechanisms by which CD57 is induced on them, and its functional consequences.

\section{CD57 EXPRESSION AND CANCER}

Both $\mathrm{CD}^{+} \mathrm{T}$ cells and $\mathrm{NK}$ cells are able to kill tumor cells through mechanisms including perforin/granzyme-mediated cytolysis and TRAIL- or FAS-mediated apoptosis (36). Accumulation of $\mathrm{CD} 7^{+} \mathrm{CD}^{+} \mathrm{T}$ cells is seen frequently in individuals with various forms of cancer (37) and has been associated with reduced survival in those with renal cell carcinoma (38), melanoma (39), gastric carcinoma (40), multiple myeloma (41), lymphomas, acute and chronic myeloid, and lymphocytic leukemias (42), among many other examples. CD57 expression on CD4 ${ }^{+} \mathrm{T}$ cells has also been associated with Hodgkin's lymphoma (43) and chronic lymphocytic leukemia (44). This association between malignancy and expanded populations of $\mathrm{CD} 57^{+} \mathrm{T}$ cells is likely explained by persistent stimulation of these cells by tumor-associated antigens in the absence of effective tumor clearance (45).

NK cells were initially identified by their ability to kill malignant cells (46-48) and a large body of clinical and experimental evidence now supports their crucial role in cancer immunosurveillance (49). Reduced MHC Class I expression (50) and de novo expression of stress related molecules (such as B7-H6, MICA, MICB, RAE-1, MULT1, and members of the ULBP family) in malignant cells alter the balance of inhibitory (via KIRs and NKG2-CD94 heterodimers) and activating (via NCRs and NKG2D homodimers) signals for NK cells (51), leading to their activation. High frequencies of peripheral or tumor-associated $\mathrm{CD} 57^{+} \mathrm{NK}$ cells are reported in cancer patients and - in sharp contrast to what has been seen for $\mathrm{CD} 8^{+} \mathrm{T}$ cells - have frequently been linked to less severe disease and better outcomes (Table 1). This would be consistent with enhanced tumor surveillance/cytotoxicity of the mature, $\mathrm{CD}_{57}{ }^{+} \mathrm{NK}$ cell subset (29); whether these associations are confounded by HCMV infection status (see below) is currently unclear. In the case of advanced gastrointestinal stromal tumors treated with the chemotherapeutic agent imatinib mesylate, NK cell secretion of IFN- $\gamma$ after IL-12/IL-2 stimulation was correlated with improved long-term survival (52). Since CD57$\mathrm{NK}$ cells are the major subset producing IFN- $\gamma$ in response to cytokines, this suggests that a heterogeneous NK cell population comprising both $\mathrm{CD}^{-} 7^{-}$and $\mathrm{CD} 7^{+}$subsets may be optimal for combating neoplasia. Clearly further studies, ideally longitudinal in nature and accompanied by data on potentially confounding factors, are needed to determine the roles of different NK cell subsets in combating different types of malignancies.

\section{CD57 EXPRESSION AND AUTOIMIMUNITY}

Autoimmune diseases tend to be highly antigen-specific and mediated by autoantibodies or autoreactive T cells. In general, expanded populations of autoreactive $\mathrm{CD}^{+} 7^{+} \mathrm{T}$ cells are associated with more severe disease - Wegener's granulomatosis (65), pars planitis (25), multiple sclerosis (MS) (66), type I diabetes mellitus (67), Graves' disease (68), and rheumatoid arthritis (RA) (69), amongst others. This likely reflects killing of vital host cells by these highly cytotoxic lymphocytes (68), although the loss of T cells with immunosuppressive potential may also play a role (67).

Perhaps surprisingly, autoimmune disease is consistently associated with reduced frequencies or absolute numbers of circulating $\mathrm{CD}^{+} 7^{+}$NK cells and/or impaired NK cell cytotoxicity (Table 2 ) (70-78), suggesting that cytotoxic CD $57^{+}$NK cells may play a regulatory role, preventing or suppressing autoimmune disease. In MS, peripheral NK cells lose expression of FAS during relapse and regain it during remission (70) and $\mathrm{FAS}^{+} \mathrm{NK}$ cells can inhibit myelin basic protein-specific T cell IFN- $\gamma$ responses (79), suggesting that NK cells may regulate autoreactive T cells. On the other hand, chronic NK cell lymphocytosis (which is associated with peripheral neuropathy, arthritis, and vasculitis) is characterized by increased absolute numbers of circulating immature NK cells with low cytotoxicity $(80,81)$. Similarly, NK cells have been found in the inflammatory infiltrates of psoriatic skin lesions (82), in synovial fluid of joints affected by RA (83), and in pancreatic islets of type I diabetes patients (84). NK cells in the synovial fluid of patients with RA, and those infiltrating psoriatic skin lesions, are immature $\mathrm{CD}_{56}{ }^{\text {bright }}$ or $\mathrm{CD}^{-} 7^{-}$and able to secrete $\operatorname{IFN}-\gamma$ and TNF $(85,86)$, suggesting that they may contribute to the inflammation rather than suppress it (84).

Taken together, these data are consistent with the hypothesis that immature $\mathrm{CD}^{-} 7^{-} \mathrm{NK}$ cells may contribute to autoimmune inflammation and tissue damage whereas more highly differentiated, cytotoxic, $\mathrm{CD}^{2} 7^{+} \mathrm{NK}$ cells may fulfill an immunoregulatory role, possibly deleting chronically activated $\mathrm{T}$ cells, as in viral hepatitis (103).

\section{CD57 EXPRESSION DURING INFECTION}

Chronic viral infections such as HCMV (104), human immunodeficiency virus (HIV) (105), hepatitis C virus (106), and EpsteinBarr virus (EBV) (107) infections offer some of the clearest examples of expansion of $\mathrm{CD} 57^{+} \mathrm{CD} 8^{+} \mathrm{T}$ cells, presumably as a result of persistent antigenic stimulation, and increased proportions of $\mathrm{CD} 7^{+} \mathrm{CD} 8{ }^{+} \mathrm{T}$ cells have also been reported in those infected with human parvovirus (108), measles (109), pulmonary tuberculosis (92), and toxoplasmosis (93). The majority of these $\mathrm{CD} 57^{+} \mathrm{CD} 8^{+}$ $\mathrm{T}$ cells, at least in HCMV infection, appear to be antigen-specific and their presence is associated with a low incidence of reactivation $(94,95)$. Similar skewing of NK cells toward the CD57 ${ }^{+}$phenotype is now reported in a variety of viral infections (Table 2).

Increased frequencies of $\mathrm{CD} 57^{+} \mathrm{CD} 16^{+} \mathrm{NK}$ cells were first reported in HCMV-infected individuals by Gratama et al. (110) and have been repeatedly confirmed $(99,111,112)$. Studies of hematopoietic stem cell transplantation (HSCT) have been particularly informative, allowing detailed comparison of stem cell differentiation into NK cells in HCMV-infected and uninfected transplant recipients $(111,112)$ with rapid and persistent expansion of $\mathrm{CD} 7^{+} \mathrm{NK}$ cells that are also $\mathrm{NKG}_{2} \mathrm{C}^{+}, \mathrm{KIR}^{+}, \mathrm{CD}_{158 \mathrm{~b}}{ }^{+}$, and potent producers of IFN- $\gamma$ after stimulation with MHC Class I-deficient target cells, only in the HCMV-infected group (111). We now know that HCMV drives expansion of NKG2C ${ }^{+}$NK cells and 
Table 1 | Associations between cancer prognosis and CD57 expression by NK cells.

\begin{tabular}{|c|c|c|}
\hline Cancer type & Observations & Reference \\
\hline $\begin{array}{l}\text { Acute lymphoblastic } \\
\text { leukemia }\end{array}$ & $\begin{array}{l}\text { Increased NK cell activity and increased numbers of } \mathrm{CD}^{2} 7^{+} \text {and } \mathrm{CD} 16^{+} \mathrm{NK} \text { cells in bone marrow } \\
\text { associated with complete remission }\end{array}$ & Sorskaar et al. (57) \\
\hline Hodgkin's disease & $\begin{array}{l}\text { Absence/low number of } \mathrm{CD}^{+} 7^{+} \mathrm{NK} \text { cells in tumor tissue (by immunohistochemistry) associated } \\
\text { with relapse }\end{array}$ & Ortaç et al. (58) \\
\hline Non-Hodgkin's lymphoma & $\begin{array}{l}\text { Higher numbers of intratumoral } \mathrm{CD} 57^{+} \mathrm{NK} \text { cells are associated with relapse free survival in } \\
\text { pediatric cases }\end{array}$ & Ortaç et al. (58) \\
\hline $\begin{array}{l}\text { Metastatic tumors in the } \\
\text { brain }\end{array}$ & $\begin{array}{l}\text { CD57+ NK cells infiltrate brain metastases of various origins (lung, breast, and renal carcinomas; } \\
\text { melanoma) but no correlation between numbers of infiltrating CD57 }{ }^{+} \mathrm{NK} \text { cells and apoptosis of } \\
\text { malignant cells }\end{array}$ & Vaquero et al. (59) \\
\hline Colorectal cancer & $\begin{array}{l}\text { Increased } \mathrm{CD}^{+} 7^{+} \mathrm{NK} \text { cells in germinal centers of draining lymph nodes, but rarely in primary or } \\
\text { metastatic lesions; CD57+ NK cells may prevent establishment of tumor in lymph nodes? }\end{array}$ & Adachi et al. (60) \\
\hline Bladder carcinoma & $\begin{array}{l}\text { Lower frequency of } \mathrm{CD}^{+} 6^{+} \text {and } \mathrm{CD} 57^{+} \mathrm{PBMC} \text { in patients with invasive and non-invasive tumors } \\
\text { is correlated with reduced cytotoxicity against T24 bladder cancer cell line }\end{array}$ & Hermann et al. (61) \\
\hline Breast carcinoma & $\begin{array}{l}\text { Survival is positively correlated with the number of tumor infiltrating CD57+ }{ }^{+} \mathrm{NK} \text { cells and with } \\
\text { expression of CX3CL1 (a known NK cell chemoattractant) by the tumor cells }\end{array}$ & Park et al. (62) \\
\hline Gastric carcinoma & $\begin{array}{l}\text { CD57+ NK cell infiltration associated with a lower clinical grade tumor, reduced venous invasion, } \\
\text { fewer lymph node metastases, less lymphocytic invasion, and increased } 5 \text { year survival outcome }\end{array}$ & Ishigami et al. (63) \\
\hline $\begin{array}{l}\text { Oral squamous cell } \\
\text { carcinoma }\end{array}$ & $\begin{array}{l}\text { Low density of tumor infiltrating } \mathrm{CD} 7^{+}{ }^{+} \mathrm{NK} \text { cells and high numbers of } \mathrm{TNF}^{+} \text {cells associated } \\
\text { with higher clinical staging }\end{array}$ & $\begin{array}{l}\text { Turkseven and Oygur } \\
\text { (64) }\end{array}$ \\
\hline $\begin{array}{l}\text { Esophageal squamous cell } \\
\text { carcinoma }\end{array}$ & Tumor infiltrating CD57+ NK cells positively associated with increased survival over 80 months & Lv et al. (87) \\
\hline $\begin{array}{l}\text { Squamous cell lung } \\
\text { carcinoma }\end{array}$ & $\begin{array}{l}\text { Tumor infiltrating CD57+ NK cells positively correlated with increased survival } 2 \text { years after } \\
\text { surgery }\end{array}$ & Villegas et al. (88) \\
\hline Pulmonary adenocarcinoma & Higher absolute numbers of tumor infiltrating $\mathrm{CD} 57^{+} \mathrm{NK}$ cells correlated with tumor regression & Takanami et al. (89) \\
\hline Various & $\begin{array}{l}\text { Low numbers of CD57+ NK cells in peripheral blood are associated with carcinomas of colon, } \\
\text { lung, breast, and neck; no association was with melanoma or sarcoma }\end{array}$ & Balch et al. (90) \\
\hline
\end{tabular}

that these cells preferentially acquire CD57 (97-99, 111, 112). In HCMV-uninfected donors, there are roughly equal proportions of $\mathrm{CD}_{57}{ }^{+} \mathrm{NKG} 2 \mathrm{C}^{+}$and $\mathrm{CD} 57^{-} \mathrm{NKG}^{2} \mathrm{C}^{+} \mathrm{NK}$ cells whereas the ratio of $\mathrm{CD}_{57}{ }^{+} \mathrm{NKG}_{2} \mathrm{C}^{+}$to $\mathrm{CD}^{-} 7^{-} \mathrm{NKG} 2 \mathrm{C}^{+} \mathrm{NK}$ cells ranges from $<1$ to $>60$ in HCMV-infected donors (99); whether this variation reflects varying duration of HCMV infection is not known. HCMV reactivation after $\mathrm{HSCT}$ is associated with a threefold increase in the ratio of $\mathrm{CD}_{57} 7^{+} \mathrm{NKG} 2 \mathrm{C}^{+}$to $\mathrm{CD} 57^{-} \mathrm{NKG} 2 \mathrm{C}^{+} \mathrm{NK}$ cells within one year (111). Yet, in the absence of HCMV infection, $\mathrm{NKG}^{+} \mathrm{C}^{+}$ NK cells are no more likely to acquire CD57 than are $\mathrm{NKG}^{-} \mathrm{C}^{-}$ NK cells (112), suggesting that either binding of NKG2C to specific HCMV ligands or chronic viral infection per se drives NK cell differentiation. Importantly, $\mathrm{CD}^{+} 7^{+} \mathrm{CD} 16^{+} \mathrm{NK}$ cells can kill HCMV-infected target cells (96) and this may be dependent upon, or enhanced by, $\alpha$-HCMV antibodies (113).

While HCMV remains the clearest example of infection driving NK cell differentiation, other viral infections may cause a similar effect. For example, there is a three to fourfold expansion of the NK cell pool during acute hantavirus infection; NK cell numbers peak approximately 10 days after the onset of symptoms and remain above baseline for at least 60 days (114). This expansion is restricted to the $\mathrm{NKG}_{2} \mathrm{C}^{+} \mathrm{NK}$ cell subset and the majority of these cells are $\mathrm{CD} 57^{+}, \mathrm{KIR}^{+}$and highly responsive to $\mathrm{MHC}$ Class I-deficient target cells. Hantavirus-infected endothelial cells express high levels of the NKG2C ligand HLA-E and expansion of the $\mathrm{NKG}_{2} \mathrm{C}^{+} \mathrm{NK}$ cell subset is seen only in HCMV seropositive hantavirus patients, suggesting that hantavirus-induced HLA-E expression and/or inflammatory cytokines released during infection may drive the expansion and subsequent maturation of $\mathrm{NKG} 2 \mathrm{C}^{+} \mathrm{NK}$ cells that have been induced or "primed" by HCMV infection (114). Similarly, transient expansion of the $\mathrm{CD} 57^{+}$ $\mathrm{NKG}_{2} \mathrm{C}^{+} \mathrm{NK}$ cell population during acute chikungunya virus infection is also associated with HCMV seropositivity (115).

Expansion of the $\mathrm{NKG}_{2} \mathrm{C}^{+} \mathrm{CD} 57^{+} \mathrm{NK}$ cell subset has also been reported in $\mathrm{HCMV}^{+}$individuals with chronic hepatitis $\mathrm{B}$ and hepatitis $\mathrm{C}$ infections, although the proportions of these cells did not differ markedly from previous reports in HCMV-infected but hepatitis virus-uninfected donors, leading the investigators to conclude that HCMV, rather than viral hepatitis, is the underlying driver of NK cell differentiation (97). In line with this, no 
Table 2 | Associations between autoimmune diseases or infections and CD57 expression by NK cells.

\section{Observations}

\section{AUTOIMMUNE DISEASE}

Alopecia areata

$\mathrm{CD} 7^{+} \mathrm{NK}$ cells are significantly reduced in peripheral blood of patients with multiple foci

of alopecia

Atopic dermatitis

Reduced frequencies of CD57 ${ }^{+}$NK cells in peripheral blood of patients compared to healthy controls, with greatest reduction in the most severe cases

Sjögren's syndrome

Decreased numbers of $\mathrm{CD} 57^{+} \mathrm{NK}$ cells observed in peripheral blood of patients compared to controls

$\lg$ A nephropathy

Decreased proportion of $\mathrm{CD} 57^{+} \mathrm{CD} 16^{+}$lymphocytes in the peripheral blood of patients
compared to healthy controls

Psoriasis

INFECTION

HCMV

HIV

NK cells infiltrating skin lesions - but also unaffected skin - are predominantly CD57low

Increased proportions of CD57+ NK cells in infected individuals; CD57 expression limited

to the $\mathrm{NKG}_{2} \mathrm{C}^{+}$subset

In chronic infections, there is a loss of CD57-/dim NK cells, but the absolute number of CD57+ NK cells remains constant

Chikungunya virus

Hantavirus

Hepatitis B and

Hepatitis C

Lyme disease
Increased proportions of $\mathrm{CD}^{+} 7^{+} \mathrm{NK}$ cells after infection in $\mathrm{HCMV}^{+}$patients

$\mathrm{NKG}_{2} \mathrm{C}^{+} \mathrm{NK}$ cell subset expanded during infection in $\mathrm{HCMV}^{+}$patients and the majority of these cells are $\mathrm{CD}_{57}^{+}$

$\mathrm{NKG} \mathrm{C}^{+} \mathrm{NK}$ cell population is expanded in chronic infections, and these are predominantly $\mathrm{CD}_{57}{ }^{+}$, but co-infection with HCMV appears to be the driver of this effect

Conflicting evidence on whether chronic disease leads to a reduced proportion of CD57 ${ }^{+}$ NK cells in peripheral blood
Reference

Imai et al. (91)

Wehrmann et al. (126) and

Matsumura (127)

Struyf et al. (128)

Antonaci et al.(129)

Batista et al. (85)

Gratama et al. (110),

Lopez-Vergès et al. (99) and

Foley et al. (111, 112)

Hong et al. (100)

Petitdemange et al. (115)

Björkström et al. (114)

Béziat et al. (97)

Stricker et al. (117), Stricker and Winger (118), and Marques et al. (119) association was found between expansion of the $\mathrm{NKG}_{2} \mathrm{C}^{+} \mathrm{CD} 57^{+}$ NK cell subset and clinical indicators of hepatitis such as viral load or liver enzyme concentrations (97).

In HIV-infected individuals, the absolute number of $\mathrm{CD} 57^{+}$ NK cells is stable and comparable to HIV-negative individuals but the ratio of $\mathrm{CD}_{57}{ }^{+}$to $\mathrm{CD} 57^{-} \mathrm{NK}$ cells is higher than in uninfected individuals due to a gradual loss of CD57 ${ }^{-}$cells (which are highly dependent on monocyte and $\mathrm{T}$ cell-derived cytokines for their survival) (100). Unfortunately, the HCMV status of these subjects was not reported and may confound the comparison between the $\mathrm{HIV}^{+}$and $\mathrm{HIV}^{-}$individuals. Indeed, in another study, the positive association between frequency of $\mathrm{NKG}_{2} \mathrm{C}^{+} \mathrm{NK}$ cells and HIV-1 infection disappears when adjusted for HCMV status (101). Nonetheless, it is also the case that the frequency of $\mathrm{NKG}_{2}^{+}\left(\mathrm{CD}^{+} 7^{+}\right) \mathrm{NK}$ cells is higher in HCMV seropositive donors with HIV-1 infection than in HCMV seropositive donors without HIV-1 infection (102), suggesting either that as for hantavirus or chikungunya virus - HIV-1 infection drives expansion of the $\mathrm{HCMV}$-induced $\mathrm{NKG}_{2} \mathrm{C}^{+}$population or that HIV-1 infected individuals experience more frequent reactivation of $\mathrm{HCMV}$ which then expands the $\mathrm{NKG}_{2} \mathrm{C}^{+}$population. Significantly, $\mathrm{CD}_{57}{ }^{+} \mathrm{NK}$ cells of $\mathrm{HIV}^{+}$individuals retain a highly differentiated phenotype $\left(\mathrm{CD}_{1} 6^{+} \mathrm{KIR}^{+}\right.$perforin $\left.{ }^{+}\right)$but have defects in degranulation (100) suggesting that they may have reduced cytotoxic potential. Finally, although no association was seen between accumulation of $\mathrm{CD} 57^{+} \mathrm{NK}$ cells and recurrence of genital herpes lesions due to herpes simplex virus 2 (HSV-2) infection (116), interpretation of this study is hindered by the lack of an HSV-2-uninfected control group.

There have been very few studies of NK cell subsets in the context of bacterial or parasitic infections. Patients with chronic Lyme Disease (Borrelia burgdorferi) have lower proportions of peripheral blood $\mathrm{CD}_{57}{ }^{+} \mathrm{NK}$ cells compared to those with acute disease and uninfected controls and this phenotype was maintained for over 10 years in one person with persistent infection $(117,118)$. In contrast, no significant differences in numbers of peripheral blood $\mathrm{CD}^{-}{ }^{-} \mathrm{CD}_{57}{ }^{+}$cells were noted between patients with post-Lyme disease syndrome, individuals recovered from Lyme disease and healthy controls (119). The suggestion (118) that high frequencies of $\mathrm{CD} 57^{+}$NK cells may be a biomarker of Lyme disease progression thus seems premature, especially given the potential impact on NK cell phenotype of HCMV and other infections.

In summary, viral infections are important drivers of NK cell differentiation with HCMV playing a primary role in selecting for $\mathrm{NKG} 2 \mathrm{C}^{+} \mathrm{CD} 57^{+}$cells and other viruses driving their expansion and differentiation. 


\section{CD57 EXPRESSION AND AGING}

Given the enormous impact of infection on NK cell maturation and differentiation, it is not surprising that NK cell populations change with age, which is a proxy for cumulative exposure to infection and other physiological insults. At birth virtually no $\mathrm{T}$ cells express CD57 (120) but the proportion rises with age, reaching $20-30 \%$ in young adults (20); by 80 years of age $50-60 \%$ of CD $8^{+}$ $\mathrm{T}$ cells are $\mathrm{CD}^{2} 8^{-}$(and thus likely $\left.\mathrm{CD} 57^{+}\right)(20,121)$. Similarly, with increasing age, increasing numbers of circulating NK cells are achieved by an expansion of the $\mathrm{CD} 56^{\mathrm{dim}}$ and $\mathrm{CD} 57^{+}$subsets and an absolute, as well as a proportional, decline in CD56 $6^{\text {bright }}$ cells $(35,53-55,122-125)$. At birth, all CD56 ${ }^{\mathrm{dim}} \mathrm{NK}$ cells are CD57 ${ }^{-}$; among European adults (18-60 years of age) $25-60 \%$ of $\mathrm{CD} 56^{\mathrm{dim}} \mathrm{NK}$ cells are $\mathrm{CD} 57^{+}$and this continues to increase slightly, but significantly, after the age of 80 years (124). Interestingly, $\mathrm{CD} 56^{\mathrm{dim}} \mathrm{CD} 57^{+} \mathrm{NK}$ cells accumulate very rapidly in an African (Gambian) population reaching adult levels (20-70\%) by the age of 5 years (Goodier et al. unpublished); this may reflect very high HCMV seroprevalence rates in this age group in this community.

The increased proportion of $\mathrm{CD} 56{ }^{\mathrm{dim}} \mathrm{CD} 57^{+} \mathrm{NK}$ cells in the elderly likely explains the maintenance of NK cell cytotoxic responses despite reduced responsiveness to cytokine stimulation [reviewed in Ref. (56)], however, the significance of these changes in terms of overall immune competence is poorly understood. The gradual loss of the CD56 $6^{\text {bright }} \mathrm{NK}$ cell population, and the consequent decline in NK-derived cytokines that activate dendritic cells and monocytes, has been assumed to contribute to age-associated declines in immune competence but the potential counterbalancing effect of an increased proportion of highly cytotoxic $\mathrm{CD} 57^{+}$ NK cells has received little attention (123). Comprehensive studies are now needed to assess the cytokine-producing and cytotoxic function of individual NK cell subsets in response to cytokine stimulation as well as activation via CD16 and NCRs and the extent to which this changes with age and HCMV status.

\section{CONCLUSION AND FUTURE DIRECTIONS}

CD57 is a very useful marker of NK cell maturation, identifying cells with potent cytotoxic potential but decreased sensitivity to cytokines and reduced replicative potential. $\mathrm{CD} 57^{+} \mathrm{NK}$ cells appear to be a stable sub-population, increasing with age and exposure to pathogens (especially, but not exclusively, HCMV) and their presence is consistently associated with better outcomes in cancer and autoimmune disease. However, the majority of clinical studies have been cross-sectional, with limited follow up and data on crucial confounding factors such as HCMV infection are typically lacking. Recent studies of HSCT $(111,112)$ demonstrate the power of prospective and longer term studies in beginning to assign causality in terms of NK cell phenotype, function, and disease. Nevertheless, precise understanding of the role of CD57 expression on NK cells requires a detailed dissection of the underlying biology of CD57, about which very little is known. Given that there is no evidence that CD57 is expressed on murine NK cells, this is not a simple task. Possible approaches in human NK cells might include conducting a comprehensive analysis of NK cell molecules expressing CD57, blocking CD57 in in vitro functional NK cell assays, or manipulating expression or enzymatic activity of B3GAT1 (the key enzyme in the biosynthesis of CD57) using RNA interference or specific inhibitors.

\section{ACKNOWLEDGMENTS}

Our studies of CD57 expression on NK cells are supported by a program grant from the UK Medical Research Council (G1000808) and Carolyn M. Nielsen is supported by an MRC Ph.D., Studentship in Vaccine Research (MR/J003999/1).

\section{REFERENCES}

1. Abo T, Balch CM. A differentiation antigen of human NK and K cells identified by a monoclonal antibody (HNK-1). J Immunol (1981) 127(3):1024-9.

2. Knapp W, Rieber P, Dörken B, Schmidt RE, Stein H, vd Borne AE. Towards a better definition of human leucocyte surface molecules. Immunol Today (1989) 10(8):253-8. doi:10.1016/0167-5699(89)90135-7

3. Abo T, Cooper MD, Balch CM. Characterization of HNK-1+ (Leu-7) human lymphocytes. I. Two distinct phenotypes of human NK cells with different cytotoxic capability. J Immunol (1982) 129(4):1752-7.

4. Lanier LL, Le AM, Phillips JH, Warner NL, Babcock GF. Subpopulations of human natural killer cells defined by expression of the Leu-7 (HNK-1) and Leu-11 (NK-15) antigens. J Immunol (1983) 131(4):1789-96.

5. Manara GC, Ferrari C, De Panfilis G. HNK-1 antigen is not specific for natural killer cells. J Invest Dermatol (1988) 91(4):374-5. doi:10.1111/1523-1747. ep12476309

6. Clement LT, Grossi CE, Gartland GL. Morphologic and phenotypic features of the subpopulation of Leu-2+ cells that suppresses B cell differentiation. J Immunol (1984) 133(5):2461-8.

7. Markey AC, MacDonald DM. HNK-1 antigen is not specific for natural killer cells. J Invest Dermatol (1989) 92(5):774-5. doi:10.1111/1523-1747. ep 12722580

8. Lipinski M, Braham K, Caillaud JM, Carlu C, Tursz T. HNK-1 antibody detects an antigen expressed on neuroectodermal cells. J Exp Med (1983) 158(5):1775-80. doi:10.1084/jem.158.5.1775

9. Schuller-Petrovic S, Gebhart W, Lassmann H, Rumpold H, Kraft D. A shared antigenic determinant between natural killer cells and nervous tissue. Nature (1983) 306(5939):179-81. doi:10.1038/306179a0

10. Shioda Y, Nagura H, Tsutsumi Y, Shimamura K, Tamaoki N. Distribution of Leu 7 (HNK-1) antigen in human digestive organs: an immunohistochemical study with monoclonal antibody. Histochem J (1984) 16(8):843-54 doi:10.1007/BF01002790

11. Ando I, Tamaki K. HNK-I antibody reacts with peripheral nerves and sweat glands in the skin. Br J Dermatol (1985) 113(2):175-8. doi:10.1111/j.13652133.1985.tb02061.x

12. Bunn PA Jr, Linnoila I, Minna JD, Carney D, Gazdar AF. Small cell lung cancer, endocrine cells of the fetal bronchus, and other neuroendocrine cells express the Leu-7 antigenic determinant present on natural killer cells. Blood (1985) 65(3):764-8.

13. Lauweryns JM, Van Ranst L. Leu-7 immunoreactivity in human, monkey, and pig bronchopulmonary neuroepithelial bodies and neuroendocrine cells. J Histochem Cytochem (1987) 35(6):687-91. doi:10.1177/35.6.3106468

14. Chou DK, Ilyas AA, Evans JE, Costello C, Quarles RH, Jungalwala FB. Structure of sulfated glucuronyl glycolipids in the nervous system reacting with HNK1 antibody and some IgM paraproteins in neuropathy. J Biol Chem (1986) 261(25):11717-25.

15. Voshol H, van Zuylen CW, Orberger G, Vliegenthart JF, Schachner M. Structure of the HNK-1 carbohydrate epitope on bovine peripheral myelin glycoprotein P0. J Biol Chem (1996) 271(38):22957-60. doi:10.1074/jbc.271.38.22957

16. Ariga T, Kohriyama T, Freddo L, Latov N, Saito M, Kon K, et al. Characterization of sulfated glucuronic acid containing glycolipids reacting with $\operatorname{IgM}$ M-proteins in patients with neuropathy. J Biol Chem (1987) 262(2):848-53.

17. Künemund V, Jungalwala FB, Fischer G, Chou DK, Keilhauer G, Schachner M. The L2/HNK-1 carbohydrate of neural cell adhesion molecules is involved in cell interactions. J Cell Biol (1988) 106(1):213-23. doi:10.1083/jcb.106.1.213

18. Cebo C, Durier V, Lagant P, Maes E, Florea D, Lefebvre T, et al. Function and molecular modeling of the interaction between human interleukin 6 and its HNK-1 oligosaccharide ligands. J Biol Chem (2002) 277(14):12246-52. doi:10.1074/jbc.M106816200 
19. Sze DM, Giesajtis G, Brown RD, Raitakari M, Gibson J, Ho J, et al. Clonal cytotoxic $\mathrm{T}$ cells are expanded in myeloma and reside in the CD8(+)CD57(+)CD28(-) compartment. Blood (2001) 98(9):2817-27. doi:10. 1182/blood.V98.9.2817

20. Vallejo AN. CD28 extinction in human T cells: altered functions and the program of T-cell senescence. Immunol Rev (2005) 205:158-69. doi:10.1111/j. 0105-2896.2005.00256.x

21. Focosi D, Bestagno M, Burrone O, Petrini M. CD57+ T lymphocytes and functional immune deficiency. J Leukoc Biol (2010) 87(1):107-16. doi:10.1189/jlb. 0809566

22. Chong LK, Aicheler RJ, Llewellyn-Lacey S, Tomasec P, Brennan P, Wang EC. Proliferation and interleukin 5 production by CD8hi CD57+ T cells. Eur J Immunol (2008) 38(4):995-1000. doi:10.1002/eji.200737687

23. Brenchley JM, Karandikar NJ, Betts MR, Ambrozak DR, Hill BJ, Crotty LE, et al. Expression of CD57 defines replicative senescence and antigeninduced apoptotic death of CD8+ T cells. Blood (2003) 101(7):2711-20. doi:10.1182/blood-2002-07-2103

24. Wood KL, Twigg HL III, Doseff AI. Dysregulation of CD8+ lymphocyte apoptosis, chronic disease, and immune regulation. Front Biosci (Landmark Ed) (2009) 14:3771-81. doi:10.2741/3487

25. Pedroza-Seres M, Linares M, Voorduin S, Enrique RR, Lascurain R, Garfias Y, et al. Pars planitis is associated with an increased frequency of effector-memory CD57+ T cells. Br J Ophthalmol (2007) 91(10):1393-8. doi:10.1136/bjo.2007. 116277

26. Chattopadhyay PK, Betts MR, Price DA, Gostick E, Horton H, Roederer M, et al. The cytolytic enzymes granyzme A, granzyme B, and perforin: expression patterns, cell distribution, and their relationship to cell maturity and bright CD57 expression. J Leukoc Biol (2009) 85(1):88-97. doi:10.1189/jlb.0208107

27. Vivier E, Anfossi N. Inhibitory NK-cell receptors on T cells: witness of the past, actors of the future. Nat Rev Immunol (2004) 4(3):190-8. doi:10.1038/nri1306

28. Papagno L, Spina CA, Marchant A, Salio M, Rufer N, Little S, et al. Immune activation and CD8+ T-cell differentiation towards senescence in HIV-1 infection. PLoS Biol (2004) 2(2):E20. doi:10.1371/journal.pbio.0020020

29. Lopez-Vergès S, Milush JM, Pandey S, York VA, Arakawa-Hoyt J, Pircher H, et al. CD57 defines a functionally distinct population of mature NK cells in the human CD56dimCD16+ NK-cell subset. Blood (2010) 116(19):3865-74. doi:10.1182/blood-2010-04-282301

30. Björkström NK, Riese P, Heuts F, Andersson S, Fauriat C, Ivarsson MA, et al. Expression patterns of NKG2A, KIR, and CD57 define a process of CD56dim NK-cell differentiation uncoupled from NK-cell education. Blood (2010) 116(19):3853-64. doi:10.1182/blood-2010-04-281675

31. Abo T, Miller CA, Balch CM. Characterization of human granular lymphocyte subpopulations expressing HNK-1 (Leu-7) and Leu-11 antigens in the blood and lymphoid tissues from fetuses, neonates and adults. Eur J Immunol (1984) 14(7):616-23. doi:10.1002/eji.1830140707

32. Phillips JH, Lanier LL. A model for the differentiation of human natural killer cells. Studies on the in vitro activation of Leu-11+ granular lymphocytes with a natural killer-sensitive tumor cell, K562. J Exp Med (1985) 161(6):1464-82. doi:10.1084/jem.161.6.1464

33. Solana R, Tarazona R, Gayoso I, Lesur O, Dupuis G, Fulop T. Innate immunosenescence: effect of aging on cells and receptors of the innate immune system in humans. Semin Immunol (2012) 24(5):331-41. doi:10.1016/j.smim.2012.04. 008

34. Cichocki F, Miller JS, Anderson SK, Bryceson YT. Epigenetic regulation of NK cell differentiation and effector functions. Front Immunol (2013) 4:55. doi:10.3389/fimmu.2013.00055

35. Krishnaraj R, Svanborg A. Preferential accumulation of mature NK cells during human immunosenescence. J Cell Biochem (1992) 50(4):386-91. doi:10.1002/jcb.240500407

36. Vesely MD, Kershaw MH, Schreiber RD, Smyth MJ. Natural innate and adaptive immunity to cancer. Annu Rev Immunol (2011) 29:235-71. doi:10.1146/ annurev-immunol-031210-101324

37. Strioga M, Pasukoniene V, Characiejus D. CD8+ CD28- and CD8+ CD57+ T cells and their role in health and disease. Immunology (2011) 134(1):17-32. doi:10.1111/j.1365-2567.2011.03470.x

38. Characiejus D, Pasukoniene V, Kazlauskaite N, Valuckas KP, Petraitis T, Mauricas $\mathrm{M}$, et al. Predictive value of CD8highCD57+ lymphocyte subset in interferon therapy of patients with renal cell carcinoma. Anticancer Res (2002) 22(6B):3679-83.

39. Characiejus D, Pasukoniene V, Jonusauskaite R, Azlauskaite N, Aleknavicius E, Mauricas M, et al. Peripheral blood CD8highCD57+ lymphocyte levels may predict outcome in melanoma patients treated with adjuvant interferon-alpha. Anticancer Res (2008) 28(2B):1139-42.

40. Akagi J, Baba H. Prognostic value of CD57(+) T lymphocytes in the peripheral blood of patients with advanced gastric cancer. Int J Clin Oncol (2008) 13(6):528-35. doi:10.1007/s10147-008-0789-8

41. Sze DM, Brown RD, Yuen E, Gibson J, Ho J, Raitakari M, et al. Clonal cytotoxic T cells in myeloma. Leuk Lymphoma (2003) 44(10):1667-74. doi:10.1080/ 1042819031000097438

42. Van den Hove LE, Vandenberghe P, Van Gool SW, Ceuppens JL, Demuynck $\mathrm{H}$, Verhoef GE, et al. Peripheral blood lymphocyte subset shifts in patients with untreated hematological tumors: evidence for systemic activation of the T cell compartment. Leuk Res (1998) 22(2):175-84. doi:10.1016/S0145-2126(97) 00152-5

43. Atayar C, Poppema S, Visser L, van den Berg A. Cytokine gene expression profile distinguishes CD4+/CD57+ T cells of the nodular lymphocyte predominance type of Hodgkin's lymphoma from their tonsillar counterparts. J Pathol (2006) 208(3):423-30. doi:10.1002/path.1894

44. Serrano D, Monteiro J, Allen SL, Kolitz J, Schulman P, Lichtman SM, et al. Clonal expansion within the CD4+CD57+ and CD8+CD57+ T cell subsets in chronic lymphocytic leukemia. J Immunol (1997) 158(3):1482-9.

45. Di Girolamo W, Coronato S, Portiansky E, Laguens G. Profile of immune cells in lymph nodes draining human malignant tumors. Medicina (B Aires) (2008) 68(6):423-7.

46. Kiessling R, Klein E, Wigzell H. "Natural” killer cells in the mouse. I. Cytotoxic cells with specificity for mouse Moloney leukemia cells. Specificity and distribution according to genotype. Eur J Immunol (1975) 5(2):112-7. doi:10.1002/eji.1830050208

47. Herberman RB, Nunn ME, Lavrin DH. Natural cytotoxic reactivity of mouse lymphoid cells against syngeneic acid allogeneic tumors. I. Distribution of reactivity and specificity. Int J Cancer (1975) 16(2):216-29. doi:10.1002/ijc. 2910160205

48. Herberman RB, Nunn ME, Holden HT, Lavrin DH. Natural cytotoxic reactivity of mouse lymphoid cells against syngeneic and allogeneic tumors. II. Characterization of effector cells. Int J Cancer (1975) 16(2):230-9. doi:10.1002/ijc. 2910160205

49. Lakshmi Narendra B, Eshvendar Reddy K, Shantikumar S, Ramakrishna S. Immune system: a double-edged sword in cancer. Inflamm Res (2013) 62(9):823-34. doi:10.1007/s00011-013-0645-9

50. Bubenik J. MHC class I down-regulation: tumour escape from immune surveillance? (review). Int J Oncol (2004) 25(2):487-91.

51. Vivier E, Ugolini S, Blaise D, Chabannon C, Brossay L. Targeting natural killer cells and natural killer T cells in cancer. Nat Rev Immunol (2012) 12(4):239-52. doi:10.1038/nri3174

52. Ménard C, Blay JY, Borg C, Michiels S, Ghiringhelli F, Robert C, et al. Natural killer cell IFN-gamma levels predict long-term survival with imatinib mesylate therapy in gastrointestinal stromal tumor-bearing patients. Cancer Res (2009) 69(8):3563-9. doi:10.1158/0008-5472.CAN-08-3807

53. Abo T, Cooper MD, Balch CM. Postnatal expansion of the natural killer and keller cell population in humans identified by the monoclonal HNK-1 antibody. J Exp Med (1982) 155(1):321-6. doi:10.1084/jem.155.1.321

54. Krishnaraj R, Blandford G. Age-associated alterations in human natural killer cells. 2. Increased frequency of selective NK subsets. Cell Immunol (1988) 114(1):137-48. doi:10.1016/0008-8749(88)90261-4

55. McNerlan SE, Rea IM, Alexander HD, Morris TC. Changes in natural killer cells, the CD57CD8 subset, and related cytokines in healthy aging. J Clin Immunol (1998) 18(1):31-8. doi:10.1023/A:1023283719877

56. Gayoso I, Sanchez-Correa B, Campos C, Alonso C, Pera A, Casado JG, et al. Immunosenescence of human natural killer cells. J Innate Immun (2011) 3(4):337-43. doi:10.1159/000328005

57. Sorskaar D, Forre O, Lie SO. Increased natural-killer cell-activity and numbers of Leu-7 and Leu-11b (Cd 16)-positive cells in bone-marrow of children in remission from acute lymphoblastic-leukemia. Scand J Immunol (1989) 29(1):65-72. doi:10.1111/j.1365-3083.1989.tb01100.x 
58. Ortaç R, Aktas S, Diniz G, Erbay A, Vergin C. Prognostic role of natural killer cells in pediatric mixed cellularity and nodular sclerosing Hodgkin's disease. Anal Quant Cytol Histol (2002) 24(5):249-53.

59. Vaquero J, Zurita M, Aguayo C, Coca S. Apoptosis is not correlated with the presence of CD57+ NK-cells in brain metastases. Acta Neurochir (Wien) (2003) 145(9):773-6. doi:10.1007/s00701-003-0087-1

60. Adachi W, Usuda N, Sugenoya A, Iida F. Immune-competent cells of regional lymph-nodes in colorectal-cancer patients: 2. Immunohistochemical analysis of Leu-7+ cells. J Surg Oncol (1990) 45(4):234-41. doi:10.1002/jso.2930450406

61. Hermann GG, Petersen KR, Steven K, Zeuthen J. Reduced LAK cytotoxicity of peripheral blood mononuclear cells in patients with bladder cancer: decreased LAK cytotoxicity caused by a low incidence of CD56+ and CD57+ mononuclear blood cells. J Clin Immunol (1990) 10(6):311-20. doi:10.1007/BF00917476

62. Park MH, Lee JS, Yoon JH. High expression of CX3CL1 by tumor cells correlates with a good prognosis and increased tumor-infiltrating CD8+ T cells, natural killer cells, and dendritic cells in breast carcinoma. J Surg Oncol (2012) 106(4):386-92. doi:10.1002/jso.23095

63. Ishigami S, Natsugoe S, Tokuda K, Nakajo A, Che X, Iwashige H, et al. Prognostic value of intratumoral natural killer cells in gastric carcinoma. Cancer (2000) 88(3):577-83. doi:10.1002/(SICI)1097-0142(20000201)88:3<577: :AID-CNCR13>3.0.CO;2-V

64. Turkseven MR, Oygur T. Evaluation of natural killer cell defense in oral squamous cell carcinoma. Oral Oncol (2010) 46(5):E34-7. doi:10.1016/j. oraloncology.2010.02.019

65. Giscombe R, Wang XB, Kakoulidou M, Lefvert AK. Characterization of the expanded T-cell populations in patients with Wegener's granulomatosis. J Intern Med (2006) 260(3):224-30. doi:10.1111/j.1365-2796.2006.01688.x

66. Ratts RB, Karandikar NJ, Hussain RZ, Choy J, Northrop SC, Lovett-Racke AE, et al. Phenotypic characterization of autoreactive $\mathrm{T}$ cells in multiple sclerosis. J Neuroimmunol (2006) 178(1-2):100-10. doi:10.1016/j.jneuroim.2006.06.010

67. Mikulkova Z, Praksova P, Stourac P, Bednarik J, Strajtova L, Pacasova R, et al. Numerical defects in CD8+CD28- T-suppressor lymphocyte population in patients with type 1 diabetes mellitus and multiple sclerosis. Cell Immunol (2010) 262(2):75-9. doi:10.1016/j.cellimm.2010.02.002

68. Sun Z, Zhong W, Lu X, Shi B, Zhu Y, Chen L, et al. Association of Graves' disease and prevalence of circulating IFN-gamma-producing CD28(-) T cells. J Clin Immunol (2008) 28(5):464-72. doi:10.1007/s10875-008-9213-4

69. Wang EC, Lawson TM, Vedhara K, Moss PA, Lehner PJ, Borysiewicz LK. CD8high+ (CD57+) $\mathrm{T}$ cells in patients with rheumatoid arthritis. Arthritis Rheum (1997) 40(2):237-48. doi:10.1002/art.1780400208

70. Takahashi K, Miyake S, Kondo T, Terao K, Hatakenaka M, Hashimoto S, et al. Natural killer type 2 bias in remission of multiple sclerosis. JClin Invest (2001) 107(5):R23-9. doi:10.1172/JCI11819

71. Kastrukoff LF, Morgan NG, Zecchini D, White R, Petkau AJ, Satoh J, et al. A role for natural killer cells in the immunopathogenesis of multiple sclerosis. J Neuroimmunol (1998) 86(2):123-33. doi:10.1016/S0165-5728(98)00014-9

72. Aramaki T, Ida H, Izumi Y, Fujikawa K, Huang M, Arima K, et al. A significantly impaired natural killer cell activity due to a low activity on a per-cell basis in rheumatoid arthritis. Mod Rheumatol (2009) 19(3):245-52. doi:10.1007/s10165-009-0160-6

73. Izumi Y, Ida H, Huang M, Iwanaga N, Tanaka F, Aratake K, et al. Characterization of peripheral natural killer cells in primary Sjogren's syndrome: impaired NK cell activity and low NK cell number. J Lab Clin Med (2006) 147(5):242-9. doi:10.1016/j.lab.2006.01.001

74. Park YW, Kee SJ, Cho YN, Lee EH, Lee HY, Kim EM, et al. Impaired differentiation and cytotoxicity of natural killer cells in systemic lupus erythematosus. Arthritis Rheum (2009) 60(6):1753-63. doi:10.1002/art.24556

75. Ciampolillo A, Guastamacchia E, Amati L, Magrone T, Munno I, Jirillo E, et al. Modifications of the immune responsiveness in patients with autoimmune thyroiditis: evidence for a systemic immune alteration. Curr Pharm Des (2003) 9(24):1946-50. doi:10.2174/1381612033454270

76. Cameron AL, Kirby B, Griffiths CE. Circulating natural killer cells in psoriasis. Br J Dermatol (2003) 149(1):160-4. doi:10.1046/j.1365-2133.2003.05319.x

77. O'Gorman M, Smith R, Garrison A, Shamiyeh E, Pachman L. Lymphocyte subsets in peripheral blood from newly diagnosed, untreated patients with juvenile dermatomyositis (JDM) are associated with disease activity scores (DAS). Arthritis Rheum (2002) 46(9):S490-490.
78. Wouters CHP, Ceuppens JL, Stevens EAM. Different circulating lymphocyte profiles in patients with different subtypes of juvenile idiopathic arthritis. Clin Exp Rheumatol (2002) 20(2):239-48.

79. Takahashi K, Aranami T, Endoh M, Miyake S, Yamamura T. The regulatory role of natural killer cells in multiple sclerosis. Brain (2004) 127:1917-27. doi:10.1093/brain/awh219

80. Rabbani GR, Phyliky RL, Tefferi A. A long-term study of patients with chronic natural killer cell lymphocytosis. Br J Haematol (1999) 106(4):960-6. doi:10.1046/j.1365-2141.1999.01624.x

81. Tefferi A, Li CY, Witzig TE, Dhodapkar MV, Okuno SH, Phyliky RL. Chronic natural killer cell lymphocytosis: a descriptive clinical study. Blood (1994) 84(8):2721-5.

82. Dotta F, Censini S, van Halteren AG, Marselli L, Masini M, Dionisi S, et al. Coxsackie B4 virus infection of beta cells and natural killer cell insulitis in recentonset type 1 diabetic patients. Proc Natl Acad Sci US A (2007) 104(12):5115-20. doi:10.1073/pnas.0700442104

83. Ottaviani C, Nasorri F, Bedini C, de Pità O, Girolomoni G, Cavani A. CD56(bright)CD16(-) NK cells accumulate in psoriatic skin in response to CXCL10 and CCL5 and exacerbate skin inflammation. Eur J Immunol (2006) 36(1):118-28. doi:10.1002/eji.200535243

84. Dalbeth N, Callan MFC. A subset of natural killer cells is greatly expanded within inflamed joints. Arthritis Rheum (2002) 46(7):1763-72. doi:10.1002/ art. 10410

85. Batista MD, Ho EL, Kuebler PJ, Milush JM, Lanier LL, Kallas EG, et al. Skewed distribution of natural killer cells in psoriasis skin lesions. Exp Dermatol (2013) 22(1):64-6. doi:10.1111/exd.12060

86. de Matos CT, Berg L, Michaëlsson J, Felländer-Tsai L, Kärre K, Söderström K. Activating and inhibitory receptors on synovial fluid natural killer cells of arthritis patients: role of CD94/NKG2A in control of cytokine secretion. Immunology (2007) 122(2):291-301. doi:10.1111/j.1365-2567.2007. 02638.x

87. Lv L, Pan K, Li XD, She KL, Zhao JJ, Wang W, et al. The accumulation and prognosis value of tumor infiltrating IL-17 producing cells in esophageal squamous cell carcinoma. PLoS One (2011) 6(3):e18219. doi:10.1371/journal.pone. 0018219

88. Villegas FR, Coca S, Villarrubia VG, Jiménez R, Chillón MJ, Jareño J, et al. Prognostic significance of tumor infiltrating natural killer cells subset CD57 in patients with squamous cell lung cancer. Lung Cancer (2002) 35(1):23-8. doi:10.1016/S0169-5002(01)00292-6

89. Takanami I, Takeuchi K, Giga M. The prognostic value of natural killer cell infiltration in resected pulmonary adenocarcinoma. J Thorac Cardiovasc Surg (2001) 121(6):1058-63. doi:10.1067/mtc.2001.113026

90. Balch CM, Tilden AB, Dougherty PA, Cloud GA. Depressed levels of granular lymphocytes with natural killer (NK) cell function in 247 cancer patients. Ann Surg (1983) 198(2):192-9. doi:10.1097/00000658-198308000-00014

91. Imai R, Miura J, Numata K, Aikawa Y, Takamori K, Ogawa H. Analysis of $\mathrm{T}$ cell, activated $\mathrm{T}$ cell and NK cell subsets in peripheral blood lymphocytes from patients with alopecia areata. In: Van Neste D, Lachapelle JM, Antoine JL, editors. Trends in Human Hair Growth and Alopecia Research. Springer Netherlands (1989). p. 299-304. doi:10.1007/978-94-011-7873-0_31

92. Fateminasab FD, Shahgasempour S, Mirsaeidi SM, Tabarsi P, Mansoori $\mathrm{SD}$, Entezami Z. Increased activation and expansion of a CD57+ subset within peripheral CD8+ T lymphocytes in Mycobacterium tuberculosis-infected patients. Arch Iran Med (2006) 9(1):53-7.

93. García-Muñoz R, Rodríguez-Otero P, Galar A, Merino J, Beunza JJ, Páramo JA, et al. Expansion of CD8+CD57+ T cells in an immunocompetent patient with acute toxoplasmosis. Adv Hematol (2009) 2009:173439. doi:10.1155/2009/ 173439

94. Dolstra H, Preijers F, Van de Wiel-van Kemenade E, Schattenberg A, Galama $\mathrm{J}$, de Witte T. Expansion of CD8+CD57+ T cells after allogeneic BMT is related with a low incidence of relapse and with cytomegalovirus infection. Br J Haematol (1995) 90(2):300-7. doi:10.1111/j.1365-2141.1995.tb05150.x

95. Mendes AV, Kallas EG, Benard G, Pannuti CS, Menezes R, Dulley FL, et al. Impact of cytomegalovirus and grafts versus host disease on the dynamics of CD57+CD28-CD8+ T cells after bone marrow transplant. Clinics (Sao Paulo) (2008) 63(5):667-76. doi:10.1590/S1807-59322008000500016

96. Borysiewicz LK, Rodgers B, Morris S, Graham S, Sissons JG. Lysis of human cytomegalovirus infected fibroblasts by natural killer cells: demonstration of an 
interferon-independent component requiring expression of early viral proteins and characterization of effector cells. J Immunol (1985) 134(4):2695-701.

97. Béziat V, Dalgard O, Asselah T, Halfon P, Bedossa P, Boudifa A, et al. CMV drives clonal expansion of NKG2C+ NK cells expressing self-specific KIRs in chronic hepatitis patients. Eur J Immunol (2012) 42(2):447-57. doi:10.1002/ eji.201141826

98. Gumá M, Angulo A, Vilches C, Gómez-Lozano N, Malats N, López-Botet M. Imprint of human cytomegalovirus infection on the NK cell receptor repertoire. Blood (2004) 104(12):3664-71. doi:10.1182/blood-2004-05-2058

99. Lopez-Vergès S, Milush JM, Schwartz BS, Pando MJ, Jarjoura J, York VA, et al. Expansion of a unique CD57(+)NKG2Chi natural killer cell subset during acute human cytomegalovirus infection. Proc Natl Acad Sci U S A (2011) 108(36):14725-32. doi:10.1073/pnas.1110900108

100. Hong HS, Eberhard JM, Keudel P, Bollmann BA, Ballmaier M, Bhatnagar N, et al. HIV infection is associated with a preferential decline in less-differentiated CD56dim CD16+ NK cells. J Virol (2010) 84(2):1183-8. doi:10.1128/JVI. 01675-09

101. Gumá M, Cabrera C, Erkizia I, Bofill M, Clotet B, Ruiz L, et al. Human cytomegalovirus infection is associated with increased proportions of NK cells that express the CD94/NKG2C receptor in aviremic HIV-1-positive patients. $J$ Infect Dis (2006) 194(1):38-41. doi:10.1086/504719

102. Mela CM, Goodier MR. The contribution of cytomegalovirus to changes in NK cell receptor expression in HIV-1-infected individuals. J Infect Dis (2007) 195(1):158-9. doi:10.1086/509811 author reply 159-60,

103. Peppa D, Gill US, Reynolds G, Easom NJ, Pallett LJ, Schurich A, et al. Upregulation of a death receptor renders antiviral $\mathrm{T}$ cells susceptible to NK cell-mediated deletion. J Exp Med (2013) 210(1):99-114. doi:10.1084/jem. 20121172

104. Wallace DL, Masters JE, De Lara CM, Henson SM, Worth A, Zhang Y, et al. Human cytomegalovirus-specific CD8(+) T-cell expansions contain longlived cells that retain functional capacity in both young and elderly subjects. Immunology (2011) 132(1):27-38. doi:10.1111/j.1365-2567.2010.03334.x

105. Le Priol Y, Puthier D, Lécureuil C, Combadière C, Debré P, Nguyen C, et al. High cytotoxic and specific migratory potencies of senescent CD8+ CD57+ cells in HIV-infected and uninfected individuals. J Immunol (2006) 177(8):5145-54.

106. Manfras BJ, Weidenbach H, Beckh KH, Kern P, Möller P, Adler G, et al. Oligoclonal CD8+ T-cell expansion in patients with chronic hepatitis $\mathrm{C}$ is associated with liver pathology and poor response to interferon-alpha therapy. J Clin Immunol (2004) 24(3):258-71. doi:10.1023/B:JOCI.0000025447.23473.ab

107. Lynne JE, Schmid I, Matud JL, Hirji K, Buessow S, Shlian DM, et al. Major expansions of select CD8+ subsets in acute Epstein-Barr virus infection: comparison with chronic human immunodeficiency virus disease. J Infect Dis (1998) 177(4):1083-7. doi:10.1086/517400

108. Isa A, Kasprowicz V, Norbeck O, Loughry A, Jeffery K, Broliden K, et al. Prolonged activation of virus-specific CD8+T cells after acute B19 infection. PLoS Med (2005) 2(12):e343. doi:10.1371/journal.pmed.0020343

109. Aronsson B, Troye-Blomberg M, Smedman L. Increase of circulating $\mathrm{CD} 8+\mathrm{CD} 57+$ lymphocytes after measles infection but not after measles vaccination. J Clin Lab Immunol (2004) 53:1-12.

110. Gratama JW, Kluin-Nelemans HC, Langelaar RA, den Ottolander GJ, Stijnen T, D'Amaro J, et al. Flow cytometric and morphologic studies of HNK1+ (Leu 7+) lymphocytes in relation to cytomegalovirus carrier status. Clin Exp Immunol (1988) 74(2):190-5.

111. Foley B, Cooley S, Verneris MR, Pitt M, Curtsinger J, Luo X, et al. Cytomegalovirus reactivation after allogeneic transplantation promotes a lasting increase in educated NKG2C+ natural killer cells with potent function. Blood (2012) 119(11):2665-74. doi:10.1182/blood-2011-10-386995

112. Foley B, Cooley S, Verneris MR, Curtsinger J, Luo X, Waller EK, et al. Human cytomegalovirus (CMV)-induced memory-like NKG2C $(+)$ NK cells are transplantable and expand in vivo in response to recipient CMV antigen. J Immunol (2012) 189(10):5082-8. doi:10.4049/jimmunol.1201964

113. Wu Z, Sinzger C, Frascaroli G, Reichel J, Bayer C, Wang L, et al. Human cytomegalovirus-induced NKG2Chi CD57hi natural killer cells are effectors dependent on humoral antiviral immunity. J Virol (2013) 87(13):7717-25. doi:10.1128/JVI.01096-13

114. Björkström NK, Lindgren T, Stoltz M, Fauriat C, Braun M, Evander M, et al. Rapid expansion and long-term persistence of elevated NK cell numbers in humans infected with hantavirus. J Exp Med (2011) 208(1):13-21. doi:10.1084/jem.20100762
115. Petitdemange C, Becquart $\mathrm{P}$, Wauquier N, Béziat V, Debré $\mathrm{P}$, Leroy EM, et al. Unconventional repertoire profile is imprinted during acute chikungunya infection for natural killer cells polarization toward cytotoxicity. PLoS Pathog (2011) 7(9):e1002268. doi:10.1371/journal.ppat.1002268

116. Björkström NK, Svensson A, Malmberg KJ, Eriksson K, Ljunggren HG. Characterization of natural killer cell phenotype and function during recurrent human HSV-2 infection. PLoS One (2011) 6(11):e27664. doi:10.1371/journal. pone. 0027664

117. Stricker RB, Burrascano J, Winger E. Longterm decrease in the CD57 lymphocyte subset in a patient with chronic Lyme disease. Ann Agric Environ Med (2002) 9(1):111-3.

118. Stricker RB, Winger EE. Decreased CD57 lymphocyte subset in patients with chronic Lyme disease. Immunol Lett (2001) 76(1):43-8. doi:10.1016/S01652478(00)00316-3

119. Marques A, Brown MR, Fleisher TA. Natural killer cell counts are not different between patients with post-Lyme disease syndrome and controls. Clin Vaccine Immunol (2009) 16(8):1249-50. doi:10.1128/CVI.00167-09

120. Weekes MP, Wills MR, Mynard K, Hicks R, Sissons JG, Carmichael AJ. Large clonal expansions of human virus-specific memory cytotoxic $\mathrm{T}$ lymphocytes within the CD57+ CD28- CD8+ T-cell population. Immunology (1999) 98(3):443-9. doi:10.1046/j.1365-2567.1999.00901.x

121. Fagnoni FF, Vescovini R, Mazzola M, Bologna G, Nigro E, Lavagetto G, et al. Expansion of cytotoxic CD8+ CD28- T cells in healthy ageing people, including centenarians. Immunology (1996) 88(4):501-7. doi:10.1046/j.1365-2567.1996. d01-689.x

122. Borrego F, Alonso MC, Galiani MD, Carracedo J, Ramirez R, Ostos B, et al. NK phenotypic markers and IL2 response in NK cells from elderly people. Exp Gerontol (1999) 34(2):253-65. doi:10.1016/S0531-5565(98)00076-X

123. Chidrawar SM, Khan N, Chan YL, Nayak L, Moss PA. Ageing is associated with a decline in peripheral blood CD56bright NK cells. Immun Ageing (2006) 3:10. doi:10.1186/1742-4933-3-10

124. Le Garff-Tavernier M, Béziat V, Decocq J, Siguret V, Gandjbakhch F, Pautas E, et al. Human NK cells display major phenotypic and functional changes over the life span. Aging Cell (2010) 9(4):527-35. doi:10.1111/j.1474-9726.2010. 00584.x

125. Tilden AB, Grossi CE, Itoh K, Cloud GA, Dougherty PA, Balch CM. Subpopulation analysis of human granular lymphocytes: associations with age, gender and cytotoxic activity. Nat Immun Cell Growth Regul (1986) 5(2):90-9.

126. Wehrmann W, Reinhold U, Kukel S, Franke N, Uerlich M, Kreysel HW. Selective alterations in natural killer cell subsets in patients with atopic dermatitis. Int Arch Allergy Appl Immunol (1990) 92(3):318-22. doi:10.1159/000235196

127. Matsumura G. [Leu7 (HNK-1)-positive cells in peripheral blood and natural killer cell activity in patients with atopic dermatitis]. Nihon Hifuka Gakkai Zasshi (1990) 100(1):57-62.

128. Struyf NJ, Snoeck HW, Bridts CH, De Clerck LS, Stevens WJ. Natural killer cell activity in Sjogren's syndrome and systemic lupus erythematosus: stimulation with interferons and interleukin-2 and correlation with immune complexes. Ann Rheum Dis (1990) 49(9):690-3. doi:10.1136/ard.49.9.690

129. Antonaci S, Polignano A, Ottolenghi A, Tortorella C, Schena FP. Redistribution of natural killer (NK) cell frequency and NK cytotoxic activity in primary IgA nephropathy. Cytobios (1992) 69(276):27-34.

Conflict of Interest Statement: The authors declare that the research was conducted in the absence of any commercial or financial relationships that could be construed as a potential conflict of interest.

Received: 02 October 2013; accepted: 20 November 2013; published online: 09 December 2013.

Citation: Nielsen CM, White MJ, Goodier MR and Riley EM (2013) Functional signifcance of CD57 expression on human NK cells and relevance to disease. Front. Immunol. 4:422. doi: 10.3389/fimmu.2013.00422

This article was submitted to NK Cell Biology, a section of the journal Frontiers in Immunology.

Copyright () 2013 Nielsen, White, Goodier and Riley. This is an open-access article distributed under the terms of the Creative Commons Attribution License (CC BY). The use, distribution or reproduction in other forums is permitted, provided the original author(s) or licensor are credited and that the original publication in this journal is cited, in accordance with accepted academic practice. No use, distribution or reproduction is permitted which does not comply with these terms. 